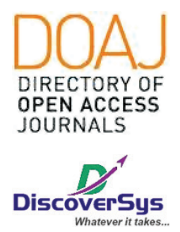

Published by DiscoverSys

\section{Hubungan stres terhadap kelelahan pada mahasiswa Fakultas Kedokteran Universitas Udayana}

CrossMark

\author{
Adela Nathania, ${ }^{1 *}$ I Made Krisna Dinata, ${ }^{2}$ I Putu Adiartha Griadhi ${ }^{2}$
}

\section{ABSTRACT}

Background: Stress can cause mental and physiological changes in a person's body, by activating the HPA axis and the autonomic nervous system. As a result, catecholamines and cortisol will be secreted and cause changes to the additional energy reserves by the body to deal with stressors and the emergence of introseptive stimuli. This energy can be depleted, causing a person to no longer have the energy to continue their activities, while introseptive stimuli cause fatigue and decreased motivation.

Methods: This analytic observational study was designed in the form of a cross sectional study of questionnaire data to measure stress and fatigue, that is distributed to 300 students of education programs for doctors in $2^{\text {nd }}, 4^{\text {th }}$, and $6^{\text {th }}$ semester of Faculty of Medicine Udayana
University in 2018. General Health Questionnaire - 12 (GHQ-12) and the 30 item Fatigue Questionnaire was used to measure stress and fatigue.

Result: 262 samples met the inclusion and exclusion criteria, 23.7\% of students experiencing stress, $1.1 \%$ experienced very high fatigue, $12.2 \%$ experienced high fatigue, $56.9 \%$ experienced moderate fatigue, and $29.8 \%$ experience low level fatigue. Stress has a significant effect with a significance value is 0.000 .

Conclusion: Stress has a relationship with fatigue in students of the Faculty of Medicine Universitar Udayana, in Bachelor of Medicine and Professionals Doctor Study Program.
1Program Studi Pendidikan Dokter ${ }^{2}$ Bagian Ilmu Faal Fakultas Kedokteran Universitas Udayana

*Corresponding: Adela Nathania, Program Studi Pendidikan Dokter, Fakultas Kedokteran Universitas Udayana

adelanathania@gmail.com

Received: 2019-01-17

Accepted: 2019-02-04

Published: 2019-04-01
Keywords: fatigue, Medical Faculty students, stress

Cite This Article: Nathania, A., Dinata, I.M.K., Griadhi, I.P.A. 2019. Hubungan stres terhadap kelelahan pada mahasiswa Fakultas Kedokteran Universitas Udayana. Intisari Sains Medis 10(1): 134-138. D0I: 10.1556/ism.v10i1.400
Latar Belakang: Stres dapat menyebabkan perubahan mental dan fisiologis tubuh seseorang, dengan mengaktivasi HPA axis dan sistem saraf otonom. Akibatnya katekolamin dan kortisol akan disekresikan dan menyebabkan bertambahnya cadangan energi tambahan untuk menghadapi stressor dan timbulnya stimuli introseptif. Energi ini dapat habis sehingga menyebabkan seseorang tidak memiliki tenaga lagi untuk melanjutkan aktivitasnya, sedangkan stimuli introseptif menyebabkan adanya persepsi kelelahan dan penurunan motivasi pada seseorang Metode: Penelitian observasional analitik ini dirancang dalam bentuk studi potong lintang dari data kuesioner untuk mengukur stress dan kelelahan yang disebarkan kepada 300 mahasiswa program studi pendidikan dokter semester 2, 4, dan 6 Fakultas Kedokteran Universitas
Udayana tahun 2018. General Health Questionnaire - 12 (GHQ-12) dan Kuesioner Kelelahan 30 item digunakan untuk mengukur stres dan kelelahan.

Hasil: 262 sampel memenuhi kriteria inklusi dan eksklusi. 23.7\% mahasiswa mengalami stres, $1.1 \%$ mengalami kelelahan tingkat sangat tinggi, $12.2 \%$ mengalami kelelahan tingkat tinggi, 56.9\% mengalami kelelahan tingkat sedang, dan $29.8 \%$ mengalami kelelahan tingkat rendah. Stres berpengaruh signifikan dengan nilai signifikansi 0.000 .

Simpulan: Stres memiliki hubungan dengan kelelahan pada mahasiswa Fakultas Kedokteran Universitar Udayana Program Studi Sarjana Kedokteran dan Profesi Dokter.

Kata kunci: kelelahan, mahasiswa Fakultas Kedokteran, stres

Cite Pasal Ini: Nathania, A., Dinata, I.M.K., Griadhi, I.P.A. 2019. Hubungan stres terhadap kelelahan pada mahasiswa Fakultas Kedokteran Universitas Udayana. Intisari Sains Medis 10(1): 134-138. D0I: 10.1556/ism.v10i1.400

\section{PENDAHULUAN}

Lingkungan perkuliahan sangat berbeda dibandingkan saat sekolah. Beban pendidikan dan tanggung jawab saat kuliah lebih tinggi terutama dalam pendidikan kedokteran, karena sesuai dengan tuntutan profesi dan tanggung jawab yang berhubungan dengan nyawa manusia. Selain itu, masih banyak faktor internal maupun eksternal seperti kurikulum dan materi dalam pendidikan kedokteran, lamanya pendidikan kedokteran, nilai akademik, biaya perkuliahan, tinggal jauh 
dari keluarga, hubungan yang kurang baik dengan teman dan staf fakultas, masalah personal, lingkungan belajar, kurangnya waktu luang, dan kurangnya waktu tidur, yang dapat memengaruhi tingkat stres pada mahasiswa kedokteran. ${ }^{1}$

Prevalensi stres pada mahasiswa kedokteran di berbagai negara beragam, mulai dari $10 \%$ sampai 96\%, dari gejala saja hingga menimbulkan morbiditas, di mana mahasiswa kedokteran memiliki tingkat morbiditas lebih besar dibandingkan mahasiswa bukan kedokteran. ${ }^{2}$ Jika stressor yang ada tidak mampu ditanggulangi oleh seseorang, maka tubuh akan merespon secara psikis maupun berakibat kepada fisik seseorang. ${ }^{3}$

Ketika dalam tekanan, akan terjadi proses psikofisiologis di mana stressor akan diproses melalui level mental terlebih dahulu, lalu diproses secara fisiologis setelahnya. Proses fisiologis akibat stres melibatkan tiga sistem, yaitu: (1) sistem saraf pusat dan perifer, (2) sistem endokrin, dan (3) sistem imun, yang saling berinteraksi dan menyekresikan hormon - hormon yang merubah homeostasis fisiologis tubuh. Masing - masing hormon dapat menyebabkan efek langsung, sedang, maupun berkepanjangan yang menyebabkan tubuh siap untuk melakukan mekanisme "Fight or Flight".

Sedangkan menurut Selye, ketika menghadapi stres berkepanjangan tubuh akan merespon melalui tiga fase, yaitu; (1) Alarm Reaction yang menyerupai respon fight or flight, (2) Resistant Phase yaitu ketika tubuh berusaha mengompensasi stressor yang ada, dan (3) Exhaustion Phase yaitu ketika tubuh tidak mampu lagi mengompensasi stressor akibat kehabisan tenaga. Dalam fase inilah burnout dan sindrom kelelahan kronis terjadi. ${ }^{5}$

Kelelahan merupakan hal yang biasa terjadi dalam kehidupan manusia akibat melakukan suatu aktivitas. Kelelahan dapat berupa kelelahan otot, kelelahan akibat stres atau depresi, maupun kelelahan akibat penyakit tertentu. ${ }^{6}$ Faktor yang memengaruhi kelelahan misalnya jenis aktivitas, durasi melakukan aktivitas, beban kerja, kondisi fisik, kondisi fisiologis, dan kondisi psikologis. Namun hubungan stres dengan kelelahan secara spesifik belum diketahui secara pasti karena penelitian terkait yang masih sedikit.

\section{METODE}

Penelitian ini merupakan penelitian potong lintang (cross sectional) untuk mengukur stress dan kelelahan pada mahasiswa program studi pendidikan dokter semester 2, 4, dan 6 Fakultas Kedokteran Universitas Udayana tahun 2018. Penelitian dilaksanakan di Fakultas Kedokteran Universitas Udayana.pada bulan Mei - Juni 2018. Besar sampel minimal dalam penelitian ini adalah 250 sample dipilih dengan metode random sampling. Kriteria inklusi yaitu, Usia 17-22 tahun, Subjek bersedia menjadi responden. Kriteria eksklusi adalah Indeks Prestasi Kumulatif $\leq 2.00$, Subjek tidak bersedia ikut serta menjadi responden. Kriteria Dropout adalah Subjek tidak mengisi kuesioner dengan lengkap.

Pengumpulan data dilakukan dengan cara mengisi kuesioner. Sebelum melakukan pengisian kuisioner dilakukan, responden dimintai persetujuan terlebih dahulu apakah bersedia untuk mengisi kuisioner atau tidak. Jika responden bersedia untuk mengisi kuisioner, selanjutnya responden diminta untuk menjawab secara lengkap pertanyaan berdasarkan kuesioner yang tersedia. Kuesioner untuk mengukur tingkat stres adalah General Health Questionnaire - 12 ( GHQ-12). GHQ-12 terdiri dari 12 pertanyaan untuk penilaian stres psikologis mandiri, untuk skrining gangguan psikologis umum terutama distress. Kuesioner untuk mengukur kelelahan adalah Subjective Self Rating Test (SSRT) yang terdiri dari 30 pertanyaan yang berhubungan dengan gejala - gejala kelelahan dalam kategori tertentu.

Data yang didapatkan berdasarkan hasil penyebaran kuesioner dianalisis dengan menggunakan bantuan program SPSS versi 20. Uji statistik yang digunakan untuk menganalisis hubungan antara variabel stres dengan kelelahan adalah uji-t (uji koefisien regresi), dengan tingkat deviasi 0,05 . Bila $\rho$ value $<0,05$, hipotesis penelitian diterima, berarti terdapat hubungan yang bermakna (signifikan) antara stress dan kelelahan.

\section{HASIL}

Tabel 1 menggambarkan karakteristik sampel penelitian dari total 262 responden. Responden wanita lebih banyak dibandingkan pria. Sebagian besar responden memiliki IMT normal yang menandakan status gizi sudah baik. Secara umum, responden tidak mengalami penyakit infeksi maupun inflamasi dalam satu bulan terakhir sejak pengisian kuesioner, sehingga $86.3 \%$ dalam kondisi sehat

Pengukuran kelelahan berdasarkan skor kelelahan 30 item terbagi ke dalam empat kategori; kelelahan tingkat rendah, kelelahan tingkat sedang, kelelahan tingkat tinggi, dan kelelahan sangat tinggi. Rerata responden mengalami kelelahan tingkat sedang (Rata - rata $=59.9 \pm$ SD 13.2), dengan sebaran distribusi seperti pada Tabel 1. Pada tingkat ini, kelelahan tidak harus mendapatkan penanganan khusus. Namun sebesar 13.3\% responden perlu penanganan kelelahan lebih lanjut karena sudah termasuk ke dalam tingkat tinggi dan sangat tinggi. 
Tabel 1 Distribusi Karakteristik Sampel Penelitian

\begin{tabular}{|c|c|c|c|}
\hline Karakteristik & & Jumlah & Persentase \\
\hline \multirow[t]{4}{*}{ Tingkat Kelelahan } & $\begin{array}{l}\text { Kelelahan sangat } \\
\text { tinggi }\end{array}$ & 3 & $1,1 \%$ \\
\hline & $\begin{array}{l}\text { Kelelahan tingkat } \\
\text { rendah }\end{array}$ & 78 & $29.8 \%$ \\
\hline & $\begin{array}{l}\text { Kelelahan tingkat } \\
\text { sedang }\end{array}$ & 149 & $56.9 \%$ \\
\hline & $\begin{array}{l}\text { Kelelahan tingkat } \\
\text { tinggi }\end{array}$ & 32 & $12.2 \%$ \\
\hline \multirow[t]{2}{*}{ Tingkat Stres } & Stres & 62 & $23,7 \%$ \\
\hline & Tidak Stres & 200 & $76,3 \%$ \\
\hline \multirow[t]{2}{*}{ Jenis Kelamin } & Wanita & 158 & $60,3 \%$ \\
\hline & Pria & 104 & $39,7 \%$ \\
\hline \multirow[t]{3}{*}{ Jenjang Semester } & Semester 2 & 89 & $34,0 \%$ \\
\hline & Semester 4 & 85 & $32,4 \%$ \\
\hline & Semester 6 & 88 & $33,6 \%$ \\
\hline \multirow[t]{2}{*}{ Status Gizi } & Tidak normal & 50 & $19,1 \%$ \\
\hline & Normal & 212 & $80,9 \%$ \\
\hline \multirow[t]{2}{*}{ Status Kesehatan } & Tidak Sehat & 36 & $13,7 \%$ \\
\hline & Sehat & 226 & $86,3 \%$ \\
\hline
\end{tabular}

Tabel 2 Uji Normalitas dengan one-sample Kolmogorov-Smirnov

\begin{tabular}{lc}
\hline & Unstandardized Residual \\
\hline $\mathrm{N}$ & 262 \\
Asymp. Sig. (2-tailed) & 0,200 \\
\hline
\end{tabular}

Tabel 3 Uji Heteroskedastisitas

\begin{tabular}{lcc}
\hline Model & $\mathbf{t}_{\text {hitung }}$ & Signifikansi \\
\hline Stres & 1,24 & 0,216 \\
Gender & 0,294 & 0,769 \\
Semester & 1,531 & 0,127 \\
IMT & 0,37 & 0,711 \\
Status Kesehatan & 1,566 & 0,119 \\
\hline
\end{tabular}

Tabel 4 Uji Multikolinearitas

\begin{tabular}{lcc}
\hline & \multicolumn{2}{c}{ Collinearity Statistics } \\
\cline { 2 - 3 } Model & Tolerance & VIF \\
\hline Stres & 0,986 & 1,014 \\
Gender & 0,985 & 1,016 \\
Semester & 0,988 & 1,012 \\
IMT & 0,972 & 1,029 \\
Penyakit & 0,982 & 1,018 \\
\hline
\end{tabular}

Hasil uji normalitas ditampilkan dalam Tabel 2, di mana nilai signifikansi $(0.200)$ lebih besar dari a (0.05) menunjukkan bahwa distribusi residu normal. Hasil uji heteroskedastisitas ditampilkan dalam Tabel 3, di mana semua variabel memiliki nilai signifikansi $>0.05$ sehingga lulus uji heteroskedastisitas. Hasil uji multikolinearitas ditampilkan dalam Tabel 4, di mana semua variabel memiliki nilai VIF $<10$ dan tolerance $>0.01$ sehingga lulus uji multikolinearitas

Ada atau tidaknya pengaruh secara simultan antara variabel bebas atau kontrol terhadap variabel terikat diuji dengan uji ANOVA untuk memeroleh nilai $\mathrm{F}$ hitung dilakukan. Hasil uji ANOVA ditampilkan dalam Tabel 5 dengan nilai signifikansi lebih kecil dari alpha 0.05. Hasil tersebut menunjukkan pengaruh antara variabel bebas dan kontrol terhadap variabel terikat secara simultan, di mana setiap perubahan yang terjadi terhadap variabel terikat (kelelahan), dapat dijelaskan oleh variabel bebas (stres) dan kontrol (jenis kelamin, status kesehatan, status gizi, dan jenjang semester) sebesar $32.5 \%$. Sisanya sebesar $67.5 \%$ dijelaskan oleh faktor lain yang tidak diuji dalam penelitian ini (Tabel 6).

Berdasarkan Tabel 7, stres memiliki pengaruh yang signifikan terhadap kelelahan (Sig. 0.000), sedangkan variabel - variabel lain seperti jenis kelamin, jenjang semester, status gizi, dan status kesehatan tidak memengaruhi kelelahan dilihat dari nilai signifikansi lebih dari 0.05 . Jadi dapat disimpulkan bahwa variabel kelelahan dipengaruhi oleh jenis kelamin, jenjang semester, status gizi, dan status kesehatan. Koefisien regresi pada variabel stres menunjukan nilai positif sebesar 1.419, sehingga apabila terjadi peningkatan sebesar 1 satuan pada stres, maka akan terjadi peningkatan pada kelelahan sebesar 1.419, kontribusi stres terhadap kelelahan adalah sebesar $32.83 \%$, sedangkan kontribusi dari variabel kontrol tidak berpengaruh dalam penelitian ini. Dapat disimpulkan ada hubungan antara stres dengan kelelahan.

\section{DISKUSI}

Tujuan utama dari penelitian ini adalah untuk membuktikan adanya hubungan antara stres dan kelelahan pada mahasiswa Fakultas Kedokteran Universitas Udayana. Ada banyak variabel yang dapat memengaruhi stres maupun kelelahan sehingga dapat menyebabkan hasil penelitian bias. Oleh karena itu peneliti mengontrol variabel variabel tersebut. Variabel yang dimaksud adalah jenis kelamin, status gizi, status kesehatan, maupun jenjang semester, di mana variabel tersebut sudah berhasil dikontrol dalam penelitian ini.

Dalam penelitian ini, stres memiliki hubungan dengan kelelahan tanpa dipengaruhi faktor lainnya. Stres menyebabkan perubahan fisiologis sebagai respon tubuh terhadap stressor. ${ }^{5}$ Stressor ini akan 
Tabel 5 ANOVA

\begin{tabular}{lcc}
\hline Model & F & Sig \\
\hline $\begin{array}{l}\text { Regresi } \\
\text { Residual }\end{array}$ & 26.129 & 0.000 \\
\hline
\end{tabular}

Tabel 6 Ringkasan Model

\begin{tabular}{lccc}
\hline Model & $\mathbf{R}$ & $\mathbf{R}^{\mathbf{2}}$ & Adjusted R Square \\
\hline 1 & $58.1 \%$ & $33.8 \%$ & $32.5 \%$ \\
\hline
\end{tabular}

Tabel 7 Model Regresi Linear Berganda

\begin{tabular}{|c|c|c|c|c|}
\hline & $\begin{array}{c}\text { Unstandardized } \\
\text { Coefficients }\end{array}$ & $\begin{array}{c}\text { Standardized } \\
\text { Coefficients }\end{array}$ & & \\
\hline Model & B & Beta & $\mathbf{t}$ & Sig. \\
\hline Konstan & 24,292 & & 2,641 & 0,009 \\
\hline Stres (X1) & 1,419 & 0,573 & 11,193 &, 000 \\
\hline Jenis Kelamin (X2) & $-0,002$ & 0 & $-0,001$ & 0,999 \\
\hline Jenjang Semester (X3) & $-0,559$ & $-0,052$ & $-1,021$ & 0,308 \\
\hline Status Gizi (X4) & $-1,821$ & $-0,041$ & $-0,789$ & 0,431 \\
\hline Status Kesehatan (X5) & 3,148 & 0,062 & 1,201 & 0,231 \\
\hline
\end{tabular}

mengaktifkan sistem saraf simpatis dan adrenokortikal sehingga memengaruhi homeostasis dan interaksi dengan lingkungan dan berperan terhadap fungsi katabolik. Perubahan tersebut dapat memengaruhi keadaan fisiologis seseorang, seperti imunitas yang menurun, gangguan kardiovaskular, peningkatan aktivitas hypothalamic-pituitary adrenal (HPA) axis kontrol. HPA axis dan sistem saraf otonom akan berintegrasi dalam menstimulasi adrenal medulla dan kortikal, di mana kelenjar tersebut akan menyekresikan katekolamin dan kortisol ke aliran darah. ${ }^{5}$ Studi potong lintang yang dilakukan oleh Doerr et al (2015) menunjukkan bahwa kadar hormon kortisol di pagi hari memiliki pengaruh positif terhadap kelelahan akut yang dirasakan seseorang yang sedang berada di bawah tekanan (stres akut). ${ }^{3}$

Kortisol dapat menyebabkan peningkatan tekanan darah, gula darah, dan menekan sistem imun tubuh. Keadaan ini berhubungan dengan penyediaan energi tambahan dan bersifat jangka panjang sehingga tubuh dapat melakukan respon baik itu menghadapi maupun lari dari ancaman atau disebut respon "Flight or Fight". ${ }^{5}$ Sedangkan sistem adrenokortikal teraktivasi ketika Corticotropin Releasing Factor (CRF) disekresikan ke kelenjar pituitari. Kelenjar pituitari akan menyekresikan serotonin dan melatonin. Serotonin akan memengaruhi tingkah laku dan perasaan seseorang, di mana penurunan serotonin berhubungan dengan depresi, sedangkan melatonin berfungsi untuk mengatur tidur, mood, dan kesadaran seseorang. Dalam keadaan stres, seseorang akan menyekresikan serotonin lebih banyak sehingga dapat menurunkan kualitas tidur. ${ }^{7}$ Kualitas tidur juga diteliti oleh Doerr et al (2015), di mana kualitas tidur menjadi salah satu mediator sehingga stres berhubungan dengan kelelahan. ${ }^{3}$

Berbagai model yang menggambarkan mekanisme stres dan kelelahan pernah dilakukan oleh Lazarus pada tahun 1966, Walter Cannon (1914) dalam model respon Fight or Flight, Hans Selye (1984) dalam model General Adaptation Syndrome (GAS), dan interaksi fisiologis sistem saraf, endokrin, dan sistem imun seperti yang digambarkan oleh Seaward (2015). ${ }^{4}$ Namun konsep GAS dari Hans Selye yang dapat menjelaskan pada penelitian ini bagaimana stres dapat berhubungan dengan kelelahan. GAS memiliki tiga fase, yang dimulai dari Alarm Reaction yang merupakan respon tubuh saat pertama kali terpapar stressor, di mana fase ini menyerupai respon Fight or Flight dari Cannon. Perubahan yang terjadi pada tubuh sebagai respon awal terhadap stressor tidak berlangsung selamanya. Jika paparan terhadap stressor terus berlanjut, energi akan berkurang dan tubuh berhenti melakukan perlawanan. Fase ini disebut fase resistensi. ${ }^{4}$

Paparan berkepanjangan dengan stressor dapat membahayakan tubuh, karena energi seseorang terbatas dan dapat habis suatu saat. Jika hal tersebut terjadi maka akan terjadi kerusakan permanen pada tubuh. Energi organisme akan terus terkuras karena melakukan perlawanan terus-menerus hingga dapat menyebabkan kematian. ${ }^{8,9}$

Hingga saat ini, masih sedikit studi yang dilakukan untuk meneliti faktor - faktor yang memengaruhi hubungan stres dan kelelahan, serta mekanisme spesifik bagaimana stres memengaruhi kelelahan secara lebih mendalam. Oleh karena itu diperlukan penelitian lebih lanjut mengenai hubungan kausalitas stres dengan kelelahan, faktor - faktor yang memengaruhi, serta mekanisme spesifik bagaimna stres dan kelelahan berhubungan.

\section{SIMPULAN}

Hasil penelitian menunjukkan ada hubungan yang signifikan antara stres dengan kelelahan pada mahasiswa Fakultas Kedokteran Universitas Udayana. Perlu adanya penelitian lebih lanjut mengenai aspek budaya, sosioekonomi, dan faktor - faktor lain yang mungkin memengaruhi hubungan stres dan kelelahan, mengingat perbedaan di setiap daerah menyebabkan karakteristik, sifat, dan respon seseorang terhadap stressor berbeda pula. Mekanisme biologis bagaimana stres dapat menyebabkan kelelahan juga dapat diteliti lebih lanjut. 


\section{DAFTAR PUSTAKA}

1. Fares J., Tabosh HA., Saadeddin Z., et al. Stress, Burnout, and Coping Strategies in Preclinical Medical Students. North American Journal of Medical Sciences. 2017. [ Online] Tersedia di: http://www.najms.org, IP: 223.255.228.109 [Diunduh: 22 September 2017].

2. Fawzy M. dan Hamed SA. Psychological Stress Among Medical Students in Assiut University Egypt. Psychiatry Research. 2017. [Online] Tersedia di: http://dx.doi. org/10.1016/j.psychres [Diunduh: 26 September 2017].

3. Doerr JM., Ditzen B., Stahler J., et al. Reciprocal Relationship Between Acute Stress and Acute Fatigue in Everyday Life in A Sample of University Students. Biological Psychology. 2015. 110; 42-9.

4. Seaward BL. Managing Stress: Principles and Strategies for Health and Well Being (8th ed). Burlingtonm MA: Jones and Bartlett Learning. 2015

5. Smit BN. The Relationship Between Burnout and Chronic Fatigue Syndrome Among Academics at A Tertiary Institution. Research Psychology in University of Pretoria (disertasi). Pretoria: Universitas Pretoria. 2015.
6. Rohlfs ICP., de Mara LS., de Lima WC., et al. Relationship of the Overtraining Syndrome with Stress, Fatigue, and Serotonin. Rev Bras Med Esporte. 2005. 11(6):333e-7e.

7. Dougall AL. dan Baum A. Stress health, and illness. In A. Baum, T. A. Revenson, \& J. Singer (Eds.), Handbook of health psychology (2nd ed., pp. 53-78). New York, NY: Psychology Press. 2012.

8. Romas JA., dan Sharma M. Understanding Stress. Practical stress management, a comprehensive workbook. (7th ed, pp. 1-5). United States; Academic Press. 2017.

9. Prasanty, N., Husada, M., Effendy, E., Simbolon, M. Workrelated psychological distress and social dysfunction in Nurses at Haji Hospital Medan-Indonesia. Bali Medical Journal. 2018. 7(2): 279-284. DOI:10.15562/bmj.v7i2.922.

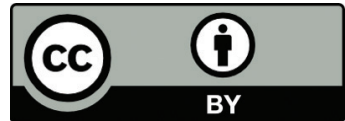

This work is licensed under a Creative Commons Attribution 